4th International Scientific Conference SEC-IASR 2019,

Galati, Romania, 7th - 8th June, 2019

\title{
The Role of the Cash Flow Table in Substantiating Effective Management Decisions in Sports Organizations
}

\author{
Florentina MOISESCU \\ https://doi.org/10.18662/lumproc/sec-iasr2019/26
}

How to cite: Moisescu, F. (2020). The Role of the Cash Flow Table in Substantiating Effective Management Decisions in Sports Organizations. In S. Marin \& P. Moisescu (vol. eds.), Lumen Proceedings: Vol. 12. 4th International Scientific Conference SEC-LASR 2019 (pp. 246-251). Iasi, Romania: LUMEN Publishing House. https://doi.org/10.18662/lumproc/sec-iasr2019/26 


\title{
The Role of the Cash Flow Table in Substantiating Effective Management Decisions in Sports Organizations
}

\author{
Florentina MOISESCU ${ }^{1}$
}

\begin{abstract}
The paper deals with the role of the treasury in financing the activity and ensuring the sustainability of a sports organisation, the importance of assessing its ability to generate liquidity and liquidity equivalents, as well as the funding needs of the organisation.

At the level of managerial decision-making, the treasury gains more weight, the more the following question arises: How is it that we have high profit margins, but there is never enough money? Sport club managers can fall into the trap of believing that a consistent profit margin or a spectacular increase in turnover guarantees the sufficiency of cash resources. These positive aspects, however, may sometimes prove fatal to the cash resources. In this respect, the treasury represents the basis for determining short-term (solvency) and long-term (financing needs) financial analysis and management indicators, favouring the forecasting of the financial situation of the entity. From the analysis performed in this paper, we consider that the analysis of cash flow is useful for substantiating efficient management decisions by: correlating the profit (loss) with the cash; separating the activities involving cash from non-cash activities; assessing the ability of an enterprise to meet its cash payment obligations; cash flow assessment for future activities (cash-flow strategy).
\end{abstract}

Keywords: management decisions; sports organization; cash-flow strategy

\footnotetext{
${ }^{1}$ Dunarea de Jos" University of Galati, Romania, florentina.moisescu@ugal.ro 


\section{Introduction}

For the management of a sporting organisation, the treasury represents the complete financial means available to the entity to cope with payments [7]. In the event of a shortage of such financial resources, it may be possible to obtain an immediate loan in the form of: short -term bank loan, acceptance of a commercial paper (commercial credit), discount of a bill of exchange not having reached maturity, etc.

For the financial analyst concerned with ensuring the financial balance of the sporting organisation, the treasury shall reflect the difference between the cash funds (or liquidity) and the immediate exigibility (liabilities). In this respect, one can talk about a positive treasury (excess liquidity over immediate exigibility) or a negative treasury, the opposite.

The summary document presenting the treasury is called the Treasury Cash Flow Table [3]. It is part of an entity's annual financial situation and with its help the management of the sporting organisation can assess its ability to produce liquidity in order to establish the dividend policy and to assess the effects of major strategic decisions on investment and financing; it determines the future liquidity needs; it compares the results of the activity and evaluates investment projects; it assesses the financial flexibility of the organisation and measures the long -term financing needs.

Cash flow management is imperative for the normal course of business; all the more so as insolvent companies experience a problem of cash flow structure before insolvency [5].

\section{Elaboration of cash flow statement}

The cash flows resulting from the sporting organisation's relations with third parties and occurring in connection with the extinction of mutual banking rights and obligations are known as treasury cash flows [1]. They are grouped into three activities, namely operational, investment and financing. This grouping provides users with access to relevant information about the financial position of the company, the value of the cash and cash equivalents, and the link between the three types of activities in terms of cash disbursement and use.

Cash deposits reflect the movement of cash resources that ensure the current supply of cash accounts. Payments refer to movements of cash and cash resources on account, from the sporting organisation to its external environment that materialise in operations relating to the extinguishing 
debts, creating receivables, or other operations which generate cash outflows [4].

The current format of the cash -flow situation is the result of an evolutionary process of over a century. The structure and content of the cash flow reporting resulted from the evolution of situations involving different denominations, but in general referred to the same term, namely "funds". In Romania, these reports are not used at their fair value; they are not a common tool for managers and creditors [2].

The operational activity is the main activity generating cash and cash equivalents for the sporting organisation, it is the activity generating revenue. Cash flows generated by the exploitation activity are essential in assessing the ability of the sports club to cover its debts, to ensure financial stability and continuity in time. They are produced by revenue -generating activities, such as: subsidies from the state budget; economic activities carried out directly related to the purpose and object of the club, including the marketing of promotional materials; penalties applied to athletes, coaches and technical committees, in accordance with their own internal regulations; income from the transfer of their own athletes to other sports clubs; contributions, membership fees; donations or sponsorships; advertising; organisation of shows or sporting events; the sale of tickets for admission to sporting competitions; participation in competitions and sports demonstrations, internal or international; etc.

The investment activity is mainly characterised by the acquisition and sale / disposal of fixed assets included in the club's patrimony. The separate presentation of treasury cash flows specific to the investment activity allows the analysis of the policy of the sporting organisation to ensure the continuity of the activity, to use the financial resources disbursed from the organisational and /or financial activity for the purpose of gaining future profit. One can also analyse and measure to what extent the cash disbursed from sales of fixed assets covers the cash requirement resulting from new purchases, new investments made in the current period.

The financing activity shall include activities which have the effect of changing the size and structure of equities, as well as bank loans or loans relating to leasing contracts. The information on cash inputs and outputs from the financing activity is of interest to associates / shareholders or banking entities in order to analyse the capacity and policy of the company for dividend distribution (for sports clubs organised as joint-stock companies) or for the repayment of granted loans. 


\section{Methods of calculation for cash flows}

The treasury cash flow analysis is under the influence of the method used in their calculation. Accounting delivers two methods for determining cash flows:

a. The Direct Method, based on the use of receipts and payments generated by the three types of activities identified;

b. The Indirect Method, based on the correction of the net result with non -monetary elements and then with variations of assets in the patrimony corresponding to the identified activities.

The direct method provides additional information necessary for the estimation of future flows of funds, information that is not provided by the indirect method. However, in practice, the indirect method is usually used because of the easy way of calculation. The necessary information for the construction of the cash flow panel through the direct method is to be found in the primary accounting, based on financial documents such as bank statements and cash books. In general, the various receipts and payments represent credit and debit footings of available bank accounts and cash accounts. If it is not possible to identify receipts and payments on the basis of the company's accounting records, other sources of determination of the values of receipts and payments, such as the Balance Sheet, the Profit and Loss Account and the Balance of Trade may also be used.

\section{The rate system calculated on the basis of cash flows}

On the basis of treasury cash flows, a system of rates can be calculated to provide the necessary information for the assessment of the financial risk of the company [8], in reference to the states of liquidity and solvency.

The following relevant financial rates are recommended:

a) The rate of cash flow from the operating activity - it shows the ratio of the net cash flow from the operation to the net turnover:

$$
R_{\text {fne }}=\frac{\text { CF exploitation }}{\text { CA net }}
$$

The operating cash flow rate measures the ability of sales to generate cash, or the weighting of cash flows from the operating activity in the total net turnover. The higher the cash flow rate in the operating activity, the lower the level of financial risk.

b) The total financial debt coverage rate shows the ability of the sporting organisation to cover its financial liabilities (short and long term) through the cash flow from the operating activity: 


$$
R_{D A F T}=\frac{C F \text { exploitation }}{\text { Current financial statements }}
$$

A low level of total debt coverage draws attention on the company's solvency, the company's ability to pay off its debts on deadlines.

c) The current debt coverage rate compares the treasury cash flows generated from the business to the total amount of the short -term debt:

$$
R_{D A F T}=\frac{\text { CF exploitation }- \text { Dividends paid }}{\text { Current financial statements }}
$$

d) The financing rate of fixed assets shows the extent to which net acquisitions of fixed assets may be covered by treasury cash flows from operating activities:

$$
R_{A D c r t}=\frac{\text { CF exploitation }}{\text { Current debts }}
$$

A high value of this rate may mean either a low value of purchases of assets, fully covered by the flows released from the operating activity, or sufficiently large flows released, capable of covering purchases of assets. A small value of this rate may mean very large investments compared to the company's ability to generate operating flows (forcing investment policy) or the low ability of the company to generate cash flows as well as to invest.

e) The interest coverage rate expresses the company's ability to cover interest on financial liabilities arising from treasury cash flows in the business, reintegrated with income tax but also with interest paid during the analysed period:

$$
R_{A D d}=\frac{\text { CF exploitation }+ \text { Dividends paid }+ \text { Profit tax paid }}{\text { Interest paid }}
$$

Companies with a high level of debt record a low level of this rate. A lower level than 1 of the interest cover rate means a high financial risk from the investors' perspective.

\section{Conclusion}

Survival on an increasingly competitive market means the ability to generate cash for the payment on time of obligations to business partners. But, according to the report on financial results, not always a sports club which has profit automatically has a positive treasury [6]. The Treasury balance is monitored through the cash flow report (Cash - Flow). The discrepancy between revenue and expenditure in the accounting records and their maturity as receipts and payments is decisive for the financial fate of a sports club. As a result, there is also a need to forecast cash flows, and to 
forecast the report on cash flow. Therefore, in order to properly assess the financial balance of the enterprise, it is not enough to know only the income and profit, but also to take into account the cash flow balance at the end of the management period, to monitor the accuracy of the forecast and the size of the deviations recorded after a predetermined period. It results that the treasury is an inseparable element in tracking the financial situation of any economic agent, the purpose of managing the treasury being to ensure the financial balance of the economic agent.

\section{References:}

[1] Brezeanu P. Diagnostic financiar. Instrumente de analiza financiara. Bucureşti: Economica; 2003. 126 p.

[2] Gheorghiu A. Analiza economico-financiară la nivelul microeconomic. Bucureşti: Economică; 2004. 234 p.

[3] IAS 7. Situația fluxurilor de numerar. Available from: https://www.iasplus. com/en/ standards/ias/ias7.

[4] IFRS. Standarde internaționale de contabilitate [International accounting standards]. București: Editura CECCAR; 2013.

[5] Ilie V. Gestiunea financiară a întreprinderii. Piteşti: Editura Independenta Economică. 2003.

[6] Petrescu S. Analiză economico-financiară. Bucureşti: Editura CECCAR; 2010. $56 \mathrm{p}$.

[7] Popescu S. Politica şi strategia economico-financiară a firmelor. Bucureşti: Editura Lumina Lex; 1996.

[8] Vâlceanu GV, Georgescu RN. (coord.). Analiză economico-financiară. Ediția a 2-a. Bucureşti:Editura Economică; 2005. 399 p. 